UDC 377.011.3-052:070]:17.022.1

DOI https://doi.org/10.31470/2415-3729-2021-13-291-302

\title{
Psychological and Pedagogical Characteristics and Functions of the Future Junior Bachelors-Journalists' Image
}

\section{Y Yueyuan}

a postgraduate student

Ternopil Volodymyr Hnatiuk National Pedagogical University

$\triangle$ 2, Maksyma Kryvonosa Str., Ternopil, Ukraine, 46027

E-mail: uueuan2020@gmail.com

ORCID: http://orcid.org/0000-0003-0172-074X

Date of receipt of the article: April 16, 2021

Article accepted for publication: June 02, 2021

\section{Психолого-педагогічна характеристика та функції іміджу майбутніх молодших бакалаврів-журналістів}

\section{У Юеюань}

аспірант Тернопільського національного педагогічного університету імені Володимира Гнатюка

$\triangle$ вул. Максима Кривоноса 2, м. Тернопіль, Україна, 46027

Дата надходження статті: 16 квітня 2021 p. Стаття прийнята до друку: 02 червня 2021 р.

\begin{abstract}
The author summarizes the views of scientists on the essence of the scientific definition of the «image» in the context of pedagogical imageology. The purpose of the article is aimed at the theoretical substantiation of the essence of the scientific definition of «image» and the disclosure of the feasibility of its formation and coverage of the semantic characteristics and functional spectrum of the image. A set of theoretical methods was used to achieve this goal, namely: system-structural analysis and systematization of psychological and pedagogical developments; comparative pedagogical analysis and synthesis, deduction and induction, classification and generalization.
\end{abstract}


The results. It is found that from the psychological and pedagogical point of view, the study of the professional and personal image is carried out during: analysis of political image; determination of psychological mechanisms of its formation; research of socio-cultural aspect of the image of the future specialist; the analysis of the practical principles of an image. Based on the generalization of the positions of scientists, it is established that an image plays an important role in the professional activities of future junior bachelors-journalists. The article presents that the professional image has a psychotherapeutic effect for a future journalist. It provides sociability, responsibility, professional confidence, social activity, diplomacy, reflectivity. The article contains a list of contradictions that are resolved during the formation of students majoring in 061 Image Journalism. The author interprets the image as a complex socio-psychological-pedagogical phenomenon, that the individual forms purposefully with the view to emotional and psychological influence and creating others' impressions and opinions about the bearer of this image. The main semantic characteristics of the image are analyzed, namely: it is formed purposefully and has a specific addressee and the ultimate goal; it is recognized as an image-stereotype used as a «business» image of the individual. It is behavioral by nature and is formed in the process of practical activities. It covers the external component and elements of self-presentation and presentation. It involves a close relationship and interaction between an individual and a group image. It covers the emphasis on specific features that are characteristic of the representative of a particular profession. It depends on the characteristics of a particular society (its values, norms, traditions, attitudes). Conclusions. Based on the generalization of scientific information, the main functions of the image are characterized, which include the following: firstly, the image must have a certain expression, which is subject to a specific goal and corresponds to the real strategy; secondly, it must position a particular organization or leader in front of the target audience; thirdly, the image should motivate the individual to take an active action. In the psychological and pedagogical fields, the practical activities of college teachers in the formation of future journalists' professional image are focused on the development of the flexibility of thinking, creativity, originality and intuition. 
Key words: image, future junior bachelors-journalists, semantic characteristics of image, functions of image.

\section{References}

1. Bogdanov, E. N., Zazykin V. G. (2003). Psihologicheskie osnovy «Pablik rilejshnz» [Psychological foundations of «Public Relations»]. $\mathrm{SPb}$. : Piter [in Russian].

2. Zinchenko, V. (2008) Imidzh uchytelia, abo psykholohiia odiahu [Teacher image, or clothing psychology]. Vidkrytyi urok: Rozrobky. Tekhnolohii. Dosvid - Open lesson: Developments. Technologies. Experience, 4, 85-86. [in Ukrainian].

3. Kalyuzhnyj, A. A. (2004). Psihologiya formirovaniya imidzha uchitelya [Psychology of the teacher's image formation]. Moscow [In Russian].

4. Penkova, O. (2002). Problema imidzhu: sotsiokulturnyi i psykholoho-pedahohichnyi aspekty [The problem of image: sociocultural and psychological-pedagogical aspects]. Ridna shkola - Native School, 6, 47-48 [in Ukrainian].

5. Pochepcov, G. (1997) Imidzh: ot faraonov do prezidentov. Stroitel'stvo voobrazhaemyh mirov $v$ mife, skazke, anekdote, reklame, propagande i pablik rilejshinz [Image: from Pharaohs to Presidents. Construction of imaginary worlds in myth, fairy tale, anecdote, advertising, propaganda and public relations]. Kyiv : ADEF-Ukraina [In Russian].

6. Romanenko, O. V. (2014). Naukovi zasady vyvchennia imidzhu yak psykholohichnoi katehorii [Scientific principles of studying image as a psychological category]. Visnyk Natsionalnoho universytetu oborony Ukrainy - Visnyk National Defence Unuversity of Ukraine, 4 (41), 293-298. [in Ukrainian].

7. Soroka, O. V. (2016). Osoblyvosti formuvannia profesiinoho imidzhu maibutnikh sotsialnykh pratsivnykiv [Features of formation of professional image of future social workers]. In Sadowskiej E. \& Dasal M. (Eds.) Formy I metody pracy z uczniem ze specjalnymi potrzebami edikacyjnymi. Czestochowa, VI, 91-95 [in Ukrainian].

8. Khomulenko T. B., Padafet Yu. H., Skorynina O. V. (2005) Teoretychni ta praktychni aspekty doslidzhennia imidzhu: Monohrafiia. [Theoretical and practical aspects of image research: Monograph]. Kh., 272. [in Ukrainian]. 


\section{Вступ}

Від науковців та практиків, які працюють у системі передвищої освіти нині вимагається впровадження педагогічних інновацій в організацію освітньої діяльності здобувачів освітньо-професійного ступеня «фаховий молодший бакалавр». У психолого-педагогічній площині необхідно щоб випускники коледжів ще під час навчання були готові до майбутньої професійної діяльності за обраною спеціальністю, а також мали сформований професійний імідж. Як засвідчують реалії XXI ст., наукова дефініція «професійний імідж» доволі часто вживається у журналістиці, де спілкування між суб'єктами відбувається за допомогою феномену «іміджу».

Відзначимо, що у наукових працях С. Амінтаєвої, Л. Жарікової, А. Калюжного, Н. Тарасенко, В. Шепель та ін. доволі грунтовно розкрито ключові поняття, які окреслюють наукову дефініцію «імідж» в контексті педагогічної іміджеології. Зокрема 3'ясовано, що теоретичні та практичні аспекти іміджу багатогранні, а інституціоналізація цієї наукової дефініції має міждисциплінарний характер. Вивчення професійного та особистісного іміджу здійснювалося під час: аналізу політичного іміджу (Почепцов, 1997); визначення психологічних механізмів його формування (Зінченко, 2008); дослідження соціокультурного та психолого-педагогічного аспектів іміджу майбутнього фахівця (Пенькова, 2002); аналізу теоретичних та практичних засад іміджу (Хомуленко, Падафет \& Скориніна, 2005).

Науковці (Калюжний, 2004; Романенко, 2014) розглядають професійний імідж як фактор успіху у кар'єрі й вагомий інструмент для побудови взаємовідносин, а також як чинник, що сприяє досягненню успіху у професійній діяльності й допомагає формуванню професіоналізму. Імідж сприймається як вагомий елемент, що має позитивний вплив на конкурентоспроможність майбутнього фахівця на ринку праці. Водночас, можемо констатувати, що психолого-педагогічні механізми, які пов'язані iз формуванням іміджу майбутніх молодших бакалаврівжурналістів в процесі підготовки у коледжах не можна вважати системно вивченими. 
Mema cmammi спрямована на теоретичне обгрунтування сутності наукової дефініції «імідж» та розкриття доцільності його формування й висвітлення змістової характеристики та функціонального спектру іміджу.

\section{Матеріал і методи дослідження}

Теоретичне вивчення іміджу передбачає вирішення низки методологічних завдань, насамперед, введення категоризації поняття та розгляд його в системі інших наукових дефініцій, які розкривають найсуттєвіші змістові характеристики. Зокрема для реалізації поставленої мети було використано комплекс теоретичних методів, а саме: системно-структурний аналіз та систематизація психологічних і педагогічних напрацювань, які дали можливість обгрунтувати концептуальні засади та підходи до розуміння іміджу як наукової дефініції; порівняльно-педагогічний аналіз й синтез, дедукція й індукція, класифікація та узагальнення для уточнення типологічної характеристики іміджу, що дозволило належним чином обгрунтувати вагомість іміджу у професійній діяльності майбутніх молодших бакалаврів-журналістів та сприяло визначенню найбільш ефективних практичних шляхів для його формуванням в процесі професійної підготовки у коледжах як закладах передвищої освіти.

\section{Результати та їх обговорення}

Реалізовуючи свої професійні обов'язки, майбутні журналісти, доволі часто, замінюють побудову складного портрету свого співрозмовника його іміджем, що розглядається як знаковий замінник, який лише в загальному відображає основні риси особистості, а тому, доволі часто, перешкоджає майбутнім журналістам якісно та неупереджено реалізовувати професійні обов'язки. У тому випадку, коли журналіст володіє позитивним професійним іміджем він має змогу легко та ефективно налагоджувати контакти із суб'єктами як особистісної, так і професійної взаємодії. Професійний імідж має психотерапевтичний ефект, наділяє комунікабельністю, відповідальністю, професійною впевненістю, соціальною активністю, дипломатичністю, рефлективністю тощо.

Виходимо 3 тих позицій, що вдало сформований професійний імідж позитивно впливає не професійну кар'єру 
та особистісний розвиток фахівця, адже охоплює сформовану систему почуттів, мотиваційно-оцінних якостей, які $\epsilon$ необхідні для компетентного здійснення професійних функцій та обов’ язків. Поділяємо позицію О. Сороки про те, що «в ринкових умовах імідж дає можливість фахівцю бути затребуваним; забезпечує взаємодію з об'єктами соціального впливу в процесі професійної діяльності; зміцнює прагнення до самовдосконалення; сприяє самореалізації, зменшує професійні стреси й комплекси» (Сорока, 2016:91).

Аналіз стану практичної підготовки майбутніх молодших бакалаврів-журналістів доводить, що в теоретичній площині нині назріла нагальна потреба в уточненні наукової дефініції «професійний імідж», доцільно виявити та обгрунтувати педагогічні інновації, що забезпечать результативність та дозволять його сформувати у студентів ще під час навчання.

У нашому баченні цілеспрямована діяльність 3 формування іміджу у майбутніх журналістів, які опановують спеціальність у коледжі, позитивно вплине на розв'язання основних суперечностей, а саме між:

- вимогами сучасного ринку праці до професійної компетентності фахівців спеціальності 061 Журналістика та недосконалістю їхньої фахової підготовки у закладах передвищої освіти, яка належним чином не сприяє формуванню професійного іміджу;

- потребою вдосконалення усіх структурних складових професійного іміджу та недостатньою визначеністю механізмів реалізації цього процесу через не розробленість педагогічної технології;

- необхідністю підвищення рівня професійного іміджу майбутніх молодших бакалаврів-журналістів в процесі підготовки у закладах фахової передвищої освіти та відсутністю відповідного навчально-методичного забезпечення цього процесу;

- переважанням традиційного підходу до організації освітнього процесу та несистемним застосуванням педагогічних інновацій, які базуються на праксеологічному підході та впровадженні тренінгових й ігрових технологій під час формування іміджу. 
Поділяємо позицію О. Романенка у тому, що незалежно від виду організації, робота 3 іміджем є дуже вагомою, оскільки саме імідж $є$ найбільш ефективним способом проникнення у масову свідомість. «Відображаючи потреби масової свідомості, він легко закріплюється та зберігається в пам'яті людей. Імідж містить риси, які, 3 одного боку, представляють інтерес для комунікатора, а з іншого, - $є$ значущими для аудиторії. Основною характеристикою іміджу є його подвійна спрямованість, оскільки він має відповідати як можливостям носія, так і потребам аудиторії. Наразі розуміння іміджу розширилося до розмірів корпоративного світу та тотального комунікаційного поля навколо нього» (Романенко, 2014: 293). Беручи до уваги наведені аргументи, вважаємо, що теоретичні питання щодо сутності іміджу та методичні й практичні площини, які стосуються його формування у майбутніх молодших бакалаврів-журналістів в процесі підготовки у закладах фахової передвищої освіти $є$ доволі вагомими та потребують грунтовного аналізу.

Так, у ході дослідження було 3'ясовано, що імідж - це «емоційно забарвлений образ людини чи організації, що склався в масовій свідомості та має характер стереотипу» (Богданов, 2003:36). Наукова дефініція імідж найбільш тісно пов'язана iз такими науковими категоріями, як «рейтинг», «репутація» та «авторитет». У соціології та психології імідж часто розглядається в контексті соціальних статусів і ролей, теорії конфлікту та концепції соціальної дії. Було враховано, що визначення категорії «імідж» має акумулювати в собі елементи онтології (змісту об'єкта), гносеології (ступеня його пізнання та управління процесом його формування).

У нашому розумінні, імідж є складним соиіально-психологопедагогічним феноменом, який розглядається нами як образ, який особистість формує иілеспрямовано з метою емочійнопсихологічного впливу та створення враження, думки оточуючих про носія даного іміджу. Можемо констатувати той факт, що нині впливова особистість, громадський, або політичний діяч 3 ціллю підвищення свого рейтингу та впливу мусить створити собі відповідний імідж. Адекватний імідж, на нашу думку, виступає у якості вагомого та необхідного атрибуту 
професійної діяльності майбутнього журналіста. Тобто у майбутнього журналіста має бути створено такий імідж, який буде більш чи менш адекватним до реального образу особистості, що складається на свідомому і підсвідомому рівнях.

На основі узагальнення напрацювань О. Ворожейкіної, А. Калюжного, М. Миліневського, Г. Почепцова, О. Романенка, О. Ткаченка, П. Фролова, які займалися теоретичними та практичними аспектами вивчення іміджу, було встановлено конкретні характеристики, які є найбільш адекватними у площині іміджу майбутнього журналіста, що здобуває освіту в коледжі. Отже, до таких змістових характеристик відносимо наступні:

- по-перше, імідж формується цілеспрямовано, він має конкретного адресанта та кінцеву мету;

- по-друге, імідж розглядається як образ-стереотип, що використовується як «діловий» образ особистості;

- по-третє, імідж носить поведінковий характер й формується в процесі практичної діяльності;

- по-четверте імідж охоплює зовнішню складову та елементи самопрезентації та презентації;

- по-п'яте, спостерігається тісний взаємозв'язок та взаємовплив між індивідуальним (конкретний для визначеного реципієнта у реальному часі) та груповим (стереотипне бачення професії у цьому суспільстві) іміджем;

- по-шосте, у іміджі акцентуються конкретні риси, які є характерними для представника певного фаху (для журналіста це об'єктивність та етичність), так і універсальні для фахівця будьякого профілю (активність, ініціативність, професіоналізм);

- по-сьоме, імідж залежать від особливостей конкретного суспільства (від його цінностей, норм, традицій, установок), в якому живе особистість.

Вважаємо, що різнопланове дослідження змістових характеристик іміджу дасть змогу краще зрозуміти ті функції, на які будемо робити акцент у практичній діяльності. Так, на основі інтерпретації напрацювань О. Романенка (Романенко, 2014: 295-298) було визначено такі функції іміджу, як:

- повинен носити певне вираження, яке підпорядковане конкретній меті та відповідає реальній стратегії; 
- має позиціонувати певну організацію чи самого фахівця перед цільовою аудиторією, що грунтується на усвідомленні переваг.

- імідж має спонукати особистість до активних дій.

Таким чином, поняття іміджу $\epsilon$ складним феноменом, який виникає на грунті специфічного сплетіння різноманітних чинників, які створюють яскраву та багатокомпонентну характеристику. Наголосимо на тому, що імідж, як соціально обумовлене багатовимірне явище, виконує низку важливих функцій, які взаємодоповнюють одна одну. У психолого-педагогічній площині практична діяльність викладачів коледжів 3 формування у майбутніх журналістів професійного іміджу має бути зосереджена на розвиток у студентів гнучкості мислення, креативності, оригінальності, інтуїції. Усе ці якості забезпечать майбутнім фахівцям розвиток професійної компетентності та ефективне особистісне становлення у професії. У практичній площині доцільно впроваджувати ефективні форми й методи формування професійного іміджу, які допоможуть майбутнім фахівцям спеціальності 061 Журналістика на високому рівні виконувати свої професійні обов'язки.

\section{Висновки}

Позитивний професійний імідж журналіста виступає вагомим особистісним інструментарієм, який сприяє налагодженню ефективних контактів із суб'єктами взаємодії. Професійний імідж має психотерапевтичний ефект, наділяє комунікабельністю, відповідальністю, професійною впевненістю, соціальною активністю, дипломатичністю, рефлективністю тощо. Виходимо 3 тих позицій, що вдало сформований професійний імідж позитивно впливає не професійну кар'єру та стимулює особистісний розвиток фахівця, адже охоплює сформовану систему почуттів, мотиваційно-оцінних якостей, які є необхідні для компетентного здійснення усього спектру професійних обов'язків. Поділяємо позицію науковців про те, що саме професійний імідж має позитивний вплив на самовдосконалення та зменшення професійних стресів й комплексів у майбутніх журналістів, які здобувають освіту в коледжі.

За результатами авторського наукового пошуку підтверджено вагомість іміджу для якісної реалізації професійної 
діяльності. Встановлено, що імідж є складним феноменом, який розглядається нами як образ, який особистість формує цілеспрямовано 3 метою емоційно-психологічного впливу та створення враження, думки оточуючих про носія. Представлено змістову характеристику іміджу та висвітлено спектр функцій, які він виконує.

Перспективи наших подальших досліджень вбачаємо в розкритті ефективних шляхів формування іміджу та розробці спеціального навчально-методичного забезпечення, що охоплюватиме елементи тренінгу та базуватиметься на праксеологічному та акмеологічному підходах для впровадження в освітній процес професійної підготовки майбутніх молодших бакалаврів-журналістів в процесі підготовки у коледжах.

\section{Література}

1. Богданов Е. Н., Зазыкин В. Г. Психологические основы «Паблик рилейшнз». СПб. : Питер, 2003. 208 с.

2. Зінченко В. Імідж учителя, або психологія одягу. Відкритий урок: Розробки. Технологї. Досвід. 2008. № 4. С. 85-86.

3. Калюжный А. А. Психология формирования имиджа учителя. Москва, 2004. 94 с.

4. Пенькова О. Проблема іміджу: соціокультурний і психологопедагогічний аспекти. Рідна школа. 2002. № 6. С. 47-48.

5. Почепцов Г. Имидж: от фараонов до президентов. Строительство воображаемых миров в мифе, сказке, анекдоте, рекламе, пропаганде и паблик рилейшинз. Київ : АДЕФ-Украина, 1997. 328 c.

6. Романенко О. В. Наукові засади вивчення іміджу як психологічної категорії. Вісник Нащіонального університету оборони Украӥни. 2014. 4 (41). С. 293-298.

7. Сорока О. В. Особливості формування професійного іміджу майбутніх соціальних працівників. Problemy nowoczesnej edukacji. Formy I metody pracy z uczniem ze specjalnymi potrzebami edikacyjnymi / Pod redakcja Edyty Sadowskiej, Mateusza Dasala. Czestochowa, 2016. Tom VI. pp. 91-95.

8. Хомуленко Т. Б., Падафет Ю. Г., Скориніна О. В. Теоретичні та практичні аспекти дослідження іміджу: монографія. Харків, 2005. $272 \mathrm{c}$. 


\section{Юеюань У.}

\section{Психолого-педагогічна характеристика та функції іміджу майбутніх молодших бакалаврів-журналістів}

\section{Анотація}

Автором узагальнено погляди науковців на сутність наукової дефініції «імідж» в контексті педагогічної іміджеології. 3'ясовано, що імідж посідає вагому роль у професійній діяльності майбутніх молодших бакалаврів-журналістів, адже має психотерапевтичний ефект, наділяє комунікабельністю, відповідальністю, впевненістю, дипломатичністю. Імідж трактуємо як складний соціально-психолого-педагогічний образ, який особистість формує цілеспрямовано з метою емоційнопсихологічного впливу та створення думки оточуючих про носія даного іміджу. Проаналізовано основні змістові характеристики іміджу, а саме: формується цілеспрямовано та має конкретного адресанта і кінцеву мету; розглядається як образ-стереотип, що використовується як «діловий» образ особистості; носить поведінковий характер й формується в процесі діяльності; охоплює зовнішню складову та елементи самопрезентації та презентації; передбачає тісний взаємозв'язок та взаємовплив між індивідуальним та груповим іміджем; охоплює акцентування уваги на конкретних рисах, які $є$ характерними для представника певної спеціальності; залежать від особливостей конкретного суспільства. Охарактеризовано основні функції іміджу, до яких віднесено такі: по-перше, імідж повинен носити певне вираження, яке підпорядковане конкретній меті та відповідає реальній стратегії; по-друге, має позиціонувати певну організацію чи лідера перед цільовою аудиторією; по-третє, імідж має спонукати особистість до активних дій. Практична діяльність викладачів коледжів 3 формування у майбутніх журналістів професійного іміджу має бути зосереджена на розвиток гнучкості мислення, креативності, оригінальності та інтуїції.

Ключові слова: імідж, майбутні молодші бакалаврижурналісти, змістові характеристики іміджу, функції іміджу. 


\section{Юеюань У.}

\section{Психолого-педагогическая характеристика и функции имиджа будущих младших бакалавров-журналистов}

\section{Аннотация}

Автором обобщены взгляды ученых на сущность научной дефиниции «имидж» в контексте педагогической имиджеологии. Выяснено, что имидж занимает весомую роль в профессиональной деятельности будущих младших бакалавров-журналистов, ведь имеет психотерапевтический эффект, наделяет коммуникабельностью, ответственностью, уверенностью, дипломатичностью. Имидж рассматриваем как сложный социально-психолого-педагогический образ, который личность формирует целенаправленно с целью эмоционально-психологического воздействия и создания мнения окружающих о носителе данного имиджа. Проанализированы основные содержательные характеристики имиджа, а именно он: формируется целенаправленно и имеет конкретного адресата и конечную цель; рассматривается как образ-стереотип, что используется как «деловой» образ личности; носит поведенческий характер и формируется в процессе деятельности; охватывает внешнюю составляющую и элементы самопрезентации и презентации; предусматривает тесную взаимосвязь и взаимовлияние между индивидуальным и групповым имиджем; акцентирует внимания на конкретных чертах, которые характерны для представителя определенной специальности; зависит от особенностей конкретного общества. Охарактеризованы основные функции имиджа, к которым отнесены: во-первых, имидж должен носить определенное выражение, которое подчинено конкретной цели и соответствует реальной стратегии; во-вторых, должен позиционировать определенную организацию или лидера перед целевой аудиторией; в-третьих, имидж должен побуждать личность к активным действиям. Практическая деятельность преподавателей колледжей по формированию у будущих журналистов профессионального имиджа должна сосредоточиваться на развитии гибкости мышления, креативности, оригинальности и интуиции.

Ключевые слова: имидж, будущие молодые бакалавры-журналисты, содержательные характеристики ими 